\title{
Evaluation of Financial Sustainability of the Federal Health Institutions in Nigeria
}

\author{
By Philip Olawale Odewole ${ }^{1}$, Mary Kehinde Salawu ${ }^{1}$, Rafiu Oyesola Salawu ${ }^{1}$
}

\begin{abstract}
The study investigated the financial sustainability of the federal health institutions in Nigeria. The population of the study comprised twenty-five (25) federal health institutions from four (4) geopolitical zones and Abuja. Secondary data were sourced from Annual General Warrant from the Office of the Accountant General of the Federation and Audited Financial Statements of the Public Sector Entities. Data obtained were analyzed using Balanced Score Card techniques. The results showed that none of the sampled federal health institutions in Nigeria attained a basic standard of sustainability test, whereby the ratios of their Internally Generated Revenue to recurrent expenditure is between $(40-60) \%$ or 0.04 and 0.6 .This indicates the inability of the institutions to generate sufficient revenue independently to cover even the operational expenses in the short-run. Also, the results equally showed the highest positive operating surplus ratios of $1 \%-5 \%$ of operational sustainability indicating that the health institutions heavily depended on central authority's funding for their survival. The results further revealed that none of the federal health institutions attained both intermediate and advance standards of sustainability tests. In conclusion, federal health institutions in Nigeria are heavily dependent on central authority for sustenance. Therefore, the central authorities should roll out blueprints that will make the institutions widen their internally generated revenue capacity and reduce the reliance on central authority's funding for survival.
\end{abstract}

Keywords: Sustainability tests, IGR, bealth institution, Balanced Scorecard.

\section{Introduction}

The challenge of financial sustainability is a common puzzle in many organizations. Maintaining and sustaining financial sustainability is a critical challenge of the top echelons in all going concerns. The fate of federal health institutions in Nigeria is not different with financing mode characterized by heavy dependence on central authority for survival. Financial sustainability is the ability of an entity to develop a cobweb of diverse resource base on its own without reliance on common pool to meet its basic needs. Nigeria is a mono-product economy. The inflows from crude oil is the mainstay of the country. The reliance on inflows from the crude oil is so significant to the extent that whatever happens to oil prices in the international market has a corresponding effect on her citizenry. The sliding trend in oil revenue as a result of glut in global oil market has provoked the central authority to initiate moves that will drive the Internally Generated Revenue of the federal health institutions to attain financial sustainability and prevent sudden financial shocks. The inflows from oil in Nigeria have been dwindling with the resultant effect of fiscal crunch on public health institutions (Bassey, 2015, Nnanseh \& Akpah, 2013). The nature of financing federal health institutions is designed to focus 
mainly on central authority funding. During the oil boom in Nigeria, the federal government was responsible for financing most of the activities in the federal health institutions from the central annual budget estimates. Both the capital and recurrent expenditure are met within the national yearly appropriations. Public institutions are grouped into three: institutions that are fully funded by the central budget. This category cannot generate any internally generated revenue by themselves. They receive all financial allocations from the common pool to finance all activities. The second category is the institutions that are partly funded by the central authority. This category is allowed to generate IGR within its local operations in addition to the central authority releases to supplement the shortfalls from the center. The third category is the institutions that are not funded by the central authority but derive all its revenue locally and to meet all its financial obligations through its own Internally Generated Revenue (Salawu \& Odewole, 2020). Since the fall in oil prices, the federal government has given tall orders to all the federal health institutions to develop strategies to generate enough revenue to meet her financial obligations without reliance on central authority funding. The study is therefore anchored on the theory of constraint which states that the organization's overall performance at any particular time is limited by its weakest link. Every entity will therefore need to identify its weakest link or constraints before it can improve its performance (Goldratt,1998). The purpose of this study is to investigate the financial sustainability of the federal health institutions in Nigeria. The remainder of the paper is arranged as follows: following the introductory section, section two (2) reviews the literature, while section three (3) discusses the methodology. Section four (4) interprets the results of finding while section five (5) concludes the paper with policy recommendation.

\section{Literature Review}

Financial sustainability is a major issue to nearly all the health institutions in Nigeria. Greater percentage of their activities are funded by releases from the Federal Government. The difficulty in measuring public entity's corporate sustainability resides in the multidimensional nature of the concept (moldavska, 2017). Measuring sustainability of private firms with stock market prices is much easier than measuring the health sector sustainability performance (De Souzaunha \& Samanez, 2013, Robinson, Kleffner and Bertels, 2011, Xio, Faff, Gharghori \& Lee, 2013). Sustainability is the ability to meet the immediate needs of an entity without compromising future generations' ability to meet up with the basic needs. (Hahn \& Figge, 2011). It is all about expanding the frontiers of resource base line into a triple bottom line (Albertini, 2013). It stresses the need for entities to remain within its revenue resource to meet all its expenses without recourse to external body for financial assistance. Many scholars have opined that $90 \%$ of public sector entities in Nigeria depend largely on statutory allocations from the central authority to meet their statutory obligations (Akindele and Obiyan, 2002; Ekpo and Ndebbio, 1998). Therefore, the impact of internally generated revenue on the performance of federal health sector entities have become imperative as a result of sliding statutory allocations to the Ministries, Departments and Agencies (MDAs) (Oladejo \& Alade,2017). Federal health institutions apart from statutory allocations from the federal government, finance their various activities through the revenue generated locally within the organization such as inflows 
from revolving fund, sale of forms, proceeds from boarded items, collections from patients, admission deposits, proceeds from sale of drugs, laboratory consumables, rents on quarters etc. Therefore, internally generated revenue is the revenue that a public health entity generates within the areas of their operational limits (Douglas, 2010, Omotoso, 2009 and Olusola, 2011). Ibeogu and Ulo (2015) attributed the health sector entity's sustainable growth to the streams of incomes generated internally. Despite the various sources of income accruable to the health institutions, many of them are confronted with sustainability challenges. Since the fall in oil prices, the federal government has given a tall order to all the federal health institutions to develop strategies in order to generate enough revenue to meet their financial obligations without reliance on central authority's funding. With many of the health institutions taken up the challenge of widening their resource base, reinforcing their financial strength and mustering inner drive to attain financial sustainability, carrying out sustainability test to know their financial position becomes important. The nature of financing of federal health institutions are designed to focus mainly on central authority's funding. Many theories have been propounded to explain the relevance of sustainability concept to the health sector performance such as value creation and value destruction theories ( $\mathrm{Yu} \&$ Zhao, 2015). Value creation theory explains the reduction in risk with the entity's adoption of environmental and social responsibility while the value-destruction theory predicts the loss in focus on profitability for an entity that engages in both environmental and social responsibility. Other theories on sustainability and corporate performance subsist between these two major theories (Ali, Haithan and Nilesh, 2018). This study however differs from others by situating the theoretical framework on the theory of constraints and this forms the cornerstone that drives the entire processes of the study. The solution to the challenge of sustainability from this study will enable all stakeholders in the health sector to see the needs for driving the revenue generation capacity of the entities in order to meet up with all statutory obligations without the slightest reliance on headquarter funding for sustenance.

\section{Methodology}

The study examined the sustainability of twenty -five (25) Ministries, Departments and Agencies (MDAs) from the four geo-political zones and Abuja, in Nigeria. The population of the study comprises all the federal teaching hospitals, medical centers and other federal health institutions. Taro Yamene technique was used to arrive at the sampled size out of the entire population of the federal health institutions in the sector who are partly funded by central authority. Data were sourced from the Offices of the AccountantGeneral of the federation, Auditor -General of the federation and the Audited Financial Statements of the public sector entities. The evaluation of financial sustainability of the federal health institutions was carried out using the balance scorecard proposed by Kaplan and Norton (1992). The use of balanced scorecard is famous in public sector entities' performance measurements with many previous studies by different authors like Kloof and Martin (2000), Askin (2004) and Striteska (2010). The balanced scorecard is a prominent technique commonly adopted in measuring the financial sustainability of the public sector entities (MAB, 1997). 


\section{Measurement of the Financial Sustainability of Federal Health Sector Entity}

The financial metrics play a dominant role and are therefore frequently used as predictors of financial performance in public organizations using relevant variables (Sheh, 2014, GFOA 2003, Crawford \& Associates, 2008). The financial metrics for public sector performance measurements are as follows:

$$
\begin{aligned}
& O P F_{i t}{ }^{1}=I R_{i t} / R E_{i t} \\
& O P F_{i t}{ }^{2}=T R_{i t}-R E_{i t} / I R_{i t} \\
& F M B_{i t}=I G F_{i t} / T R G_{i t} \\
& B U P_{i t}{ }^{1}=B T R_{i t}-A T R_{i t} / B T R_{i t} \\
& B U P_{i t}{ }^{2}=B T E_{i t}-A T E_{i t} / B T E_{i t}
\end{aligned}
$$

These are financial ratios computed based on the public sector entities financial statements

\begin{tabular}{|c|c|c|c|}
\hline $\mathrm{S} / \mathrm{N}$ & Variables & Measurement & Apriori \\
\hline 1. & $\begin{array}{l}\text { Operating } \\
\text { Performance } \\
\left(\mathrm{OPF}^{1}\right)\end{array}$ & $\begin{array}{l}\text { Internally Generated Revenue } \\
(\mathrm{IGR}) / \text { Recurrent Expenditure } \\
(\mathrm{RE})\end{array}$ & $\begin{array}{l}\text { 1. Basic standard }(40-60) \% \text { or }(0.4 \text { and } \\
0.6) \text {. } \\
\text { 2. Intermediate standard }(60-90) \% \text { or }(0.6 \\
-0.9) \text {. } \\
\text { 3. Advanced standard more than } 90 \% \text { or } \\
>0.9\end{array}$ \\
\hline 2. & $\begin{array}{l}\text { Operating } \\
\text { Performance } \\
\left(\mathrm{OPF}^{2}\right)\end{array}$ & $\begin{array}{l}\text { Total Revenue (TR) - } \\
\text { Recurrent Expenditure (RE)/ } \\
\text { Internally Generated Revenue } \\
\text { (IR) }\end{array}$ & $\begin{array}{l}\text { 1. Basic standard between }(1-15) \% \text { or } 0.1 \\
-0.15 \text {. } \\
\text { 2. Advanced standard }>15 \%\end{array}$ \\
\hline 3. & $\begin{array}{l}\text { Fund } \\
\text { Mobilization } \\
\text { Performance } \\
\text { (FMP) }\end{array}$ & $\begin{array}{l}\text { Total Intergovernmental Funds } \\
\text { Received (IGF)/ Total Revenue } \\
\text { including Grants and } \\
\text { Contribution (TGR) }\end{array}$ & $\begin{array}{l}\text { High ratios is an indication of high } \\
\text { reliant on external resources for funding. }\end{array}$ \\
\hline 4. & $\begin{array}{l}\text { Budget } \\
\text { Performance } \\
\left(\mathrm{BuP}^{1}\right)\end{array}$ & $\begin{array}{l}\text { Budgeted Total Revenue (BTR) } \\
\text { - Actual Total Revenue (ATR)/ } \\
\text { Budgeted Total Revenue (BTR) }\end{array}$ & $\begin{array}{l}\text { High ratio is an indication of high } \\
\text { performance and ability to meet revenue } \\
\text { budget in internal and external source } \\
\text { while low ratio means low performance } \\
\text { and inability to meet revenue budget. }\end{array}$ \\
\hline 5. & $\begin{array}{l}\text { Budget } \\
\text { Preference } \\
\left(\mathrm{BuP}^{2}\right)\end{array}$ & $\begin{array}{l}\text { Budgeted Total Expenditure } \\
\text { (BTE) - Actual Total } \\
\text { Expenditure (ATE)/ Budgeted } \\
\text { Total Expenditure (BTE) }\end{array}$ & $\begin{array}{l}\text { Low ratio shows ability of the entity to } \\
\text { minimize cost and attain the expenditure } \\
\text { budget while high ratios show inability of } \\
\text { the entity to minimize costs. }\end{array}$ \\
\hline
\end{tabular}
and fund statements. Financial ratios are valuable tools used in measuring an organization's financial behaviour and performance (Erdogan, 2013). The operationalization of the variables are presented in Table1.

Table1: Operationalization of Financial Sustainability Variables

5. Measurements of Variables in Evaluating the Financial Sustainability of Federal Health Sector Entities

The interpretation of different ratios used in the model is as follows: In 
equations(1) and (2), variables $O P F_{i t} 1$ and $O P F_{i t} 2$ represent the health sector entities operating performance ratios for entity $i$ at time $t$, Also, $I R_{i t}$ is the total internal revenue collected by the entity from different internal sources. In the model, $R E_{i t}$ is the total recurrent expenditure of the entity at time $t, T R_{i t}$ is the total operating revenue excluding grants from outside the entity and contributions received from all sources for the capital development by the entity $\mathrm{i}$ at time t. In equation (3), variable $F M B_{i t} 1$ in the model represents fund mobilization performance ratio of health sector entity i at time t. $I G F_{i t}$ is the total intergovernmental funds received by the entity from other government agencies and parastatals $i$ at time t, while $T R G_{i t}$ is the total revenue generated including grants and contribution for the development by the health sector entity $i$ at time $t$.

In equation (4) and (5), $B U P_{i t} 1$ and $B U P_{i t} 2$, represent budget performance ratios for ith entity in time t for model 1 to $2 . A T R_{i t}$ is the actual total revenue collected for each health sector entity $\mathrm{i}$ in time $\mathrm{t}, B T R_{i t}$ is the budgeted total revenue collectible for entity $\mathrm{i}$ in time t, $A T E_{i t}$ is the actual total expenditure for entity $\mathrm{i}$ in time $\mathrm{t}$ and BTE is the budgeted total expenditure of health sector entity $\mathrm{i}$ in time $\mathrm{t}$.

In equation (1), $O P F_{i t} 1$ measures the operational sustainability of the health sector entities. It determines whether there is adequate revenue available within the entity to finance the recurrent entity's operational expenses. It is a measure of financial performance of the federal health sector entity. Inability of any of the entity to cover operating expenditure within its own resources is a symptom of over reliance on external borrowings and intergovernmental funds. When operating expenses in the organization are not met within the internally generated revenue, it is a signal that the entity is not sustainable. These entities are therefore incapacitated to operate in situation when the central government funds are unavailable or denied or delayed in any financial year. Different standards have been established to assess the varying revenue raising capacities of the health sector entities. GFOA (2003) established three distinct basis of measuring revenue raising capacities of public sector entities as basic standard, intermediate basis and advance basis. A basic standard is achieved within the health sector entity when revenue generating capacity ratio is between $40 \%$ and $60 \%$ (or 0.4 and 0.6 ). That is, an entity that is able to generate $40 \%$ of its own revenue within its operating activity to meet its recurrent expenditure attains a basic standard of revenue generating capacity. A federal health entity which fails to raise up enough revenue as much as $40 \%$ from its internal sources does not attain this standard. An intermediate standard is achieved when the ratio of internally generated revenue capacity of an entity is rated between $60 \%$ and $90 \%$ (or 0.6 and 0.9 ). An entity that attains this standard performs relatively better than those operating under the basic standard. An advanced standard of revenue capacity generation is achieved when the ratios of revenue generated capacity is greater than $90 \%$ (or $>0.9$ ) GFOA (2003). This is the optimum standard of revenue generation for all public health entities.

In equation (2), $O P F_{i t} 2$ in the model measures the ability of the public health sector entity to cover its operational cost and still have enough revenue available for capital funding or other purposes within the accounting year or thereafter in the organization. A federal health entity is sustainable if it can achieve a consistent positive operating surplus with a potential to continue in that capacity in a distant future. A negative ratio by the entity indicates the percentage increase in total own source revenue (principally rates) that 
would have been required to achieve a break-even operating result (Nollenbarger, 2003; Chaney, 2002; GFOA, 2003, Crawford \& Associate, 2008).

The basic standard is between $1 \%$ and $15 \%(0.01$ and 0.15$)$ while the advanced standard $>15 \%(>0.15)$ GFOA (2003). In equation (3) , FMB $B_{i t} 1$ measures the extent to which a public sector entity is reliant on other government for resources. A high ratio may indicate that a public sector entity is over reliant on external resources, increasing risk as external providers may alter funding streams (Nollenberyer, 2003; Chaney, 2002; GFOA, 2003; Crawford \& Associate, 2008). Equations (4) and (5) represent $B U P_{i t}$, measure the ability of the public sector entity to manage the budgets which they set in accounting period (Nollenberyer, 2003; Chaney, 2002; GFOA, 2003; Crawford \& Associate, 2008). Two ratios are used to assess the budget performance. The first addresses the ability of the public sector entity to meet the revenue budget in terms of total revenue collectible from internal and government's sources while the other ratio measure the ability of public sector entities to minimize cost and attain the expenditure budget.

\section{Interpretation of Results}

Figure1 shows the operational sustainability of the MDAs in the federal health sector within the sampled size. The figures were presented in percentages. Twenty-five federal health institutions are sampled and the sustainability test were run using balance scorecard technique. GFOA (2003) established three standards that a public health sector entity can achieve to attain operational sustainability. The first standard is a basic standard. A public health institution attains a basis standard of operational sustainability when its revenue generation ratio is between $40 \%$ and $60 \%$ (or 0.4 and 0.6 ) which is a minimum condition for an entity to remain in operation. The second standard of operational sustainability is the intermediate standard where the entity revenue generation ratio is between $60 \%$ and $90 \%$ (or 0.6 and 0.9 ). At this level the entity is considered to be sustainable whereby all recurrent expenses are easily met within the entity's own revenue resources. The third stage is advance standard. This stage is achieved if the revenue generating capacity of the entity is greater than $90 \%$ (or > 0.9) (GFOA, 2003). This is the ideal revenue generating capacity ratio for any public sector entity in measuring operational sustainability. From the arrays of generated variables for operational sustainability for the twenty-five (25) MDAs, none of the institutions achieved a basic standard of $(40 \%$ and $60 \%$ ). The implication is that within the research periods, none of the MDAs could generate enough revenue to cover operating expenditure using own source revenues. This is an indication of high dependence and reliance of the institutions on intergovernmental financial aids, grants and borrowings for sustenance. Apart from this, all the institutions in this category would find it extremely difficult to meet up with statutory commitments without the central authority's assistance. Presently, all the federal health institutions are partly funded by the central authority. By implication, the federal health institutions rely on central funding to finance core expenses. The statutory allocations like personnel costs emolument for staff, overhead cost allocation for general repairs and maintenance and capital grants for capital developments are wholly provided by the central authority. One of the financial factors that determine the financial sustainability of government parastatals is the ability to generate revenue and reduce the aggregate public expenditure 
(Kioko and Fohua, 2015). The health institutions are therefore, operationally unsustainable where it is impossible to reasonably generate enough fund internally to cover its operating expenses and overhead costs within the financial year. This inability will make it difficult for the institutions to operate in a situation where the central authority allocations are delayed, withheld or unavailable (Wgomuo and Wang, 2015).

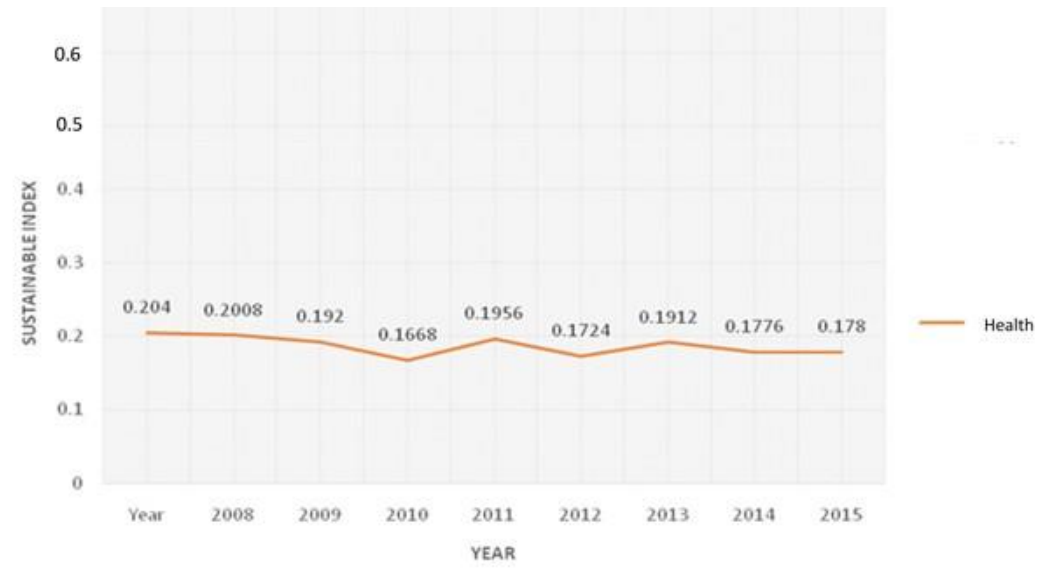

Figure 1: Operational Sustainability Index of the public health institutions on Operational sustainability Source: Authors' Computation (2019)

The above figure shows the operational sustainability index of the sampled public health institutions in the health sector

Figure 2 presents the financial sustainability of the sampled health institutions in the sector. An entity is financially sustainable if the going concern demonstrates ability to cover operational costs and still have revenues sufficiently available within the organization for capital funding, investment and developmental projects. A public entity is considered financially sustainable if on the consistent basis the entity achieves a positive operating surplus ratio with a sound long-term financial plan for the organization (Crawford and Associates,2008). The consistent capacity of an entity to attain a positive operating surplus with an investment option for a long-term financial plan provides a sound footing for the entity to be financially sustainable. An entity that cannot therefore sustain a chain of positive operating surplus in the long-run with the available asset portfolio is not financially sustainable. Operational sustainability is technically different from financial sustainability. The latter is a subset of the former. An entity can attain operational sustainability without achieving financial sustainability. Operational sustainability is a short-run concept whereas financial sustainability is a long-run concept. An entity fulfills a necessary condition for attaining operational sustainability when sufficient revenues are generated to pay for recurrent operational expenses within the organization. Attaining a financial sustainability is a sufficient condition achieved when sufficient revenue generated covers all the recurrent operational costs and the sufficient revenue balances are available for ploughing back into the organization for capital funding and project investments. There are two acid tests prescribed for financial sustainability of a public sector entity (Crawford and Associates, 
(2008), GFOA (2003), Nollengerger, (2003), Chaney et al (2002).

An entity attains a basic standard of financial sustainability when its positive operating ratios is between $1 \%$ and $15 \%(0.01$ and 0.15$)$ and advanced standard of financial sustainability is attained when the surplus operating ratio is greater than $15 \%(>0.15)$.

From figure 2 , it can be seen that the positive operating ratio is between $1 \%$ and $5 \%$. The positive operating surplus for most of the institutions skewed between $1 \%$ and $5 \%$ indicating the extent of their strength and capacity in revenue generation. The implication of this limitation is that the federal health institution operates under a constraint whereby they could hardly generate revenue large enough to cover operational costs not to think of having some balances left behind for ploughing back into the organization for capital funding or investing on capital projects like construction of roads, building and procurement of medical equipment. The sector's positive operating surplus ratios fall within the immediate basic standard of $1 \%$ and $5 \%$ suggesting that the institutions are financially constrained. They, therefore, rely heavily on allocations from central authority for physical capital development. The streams of their internal generated revenue capacity cannot accommodate massive capital project developments expansion in their entities. One can therefore say that most of the visible capital developments embarked on in most of the federal health institutions are likely financed either by the central authority through the annual appropriation on capital project budget or through debts financing sourced from Money Deposit Banks. This therefore implies that when there is a delay or withdrawal of capital projects releases to the institutions from the center, the capital project development or expansion is either negatively affected or halted.

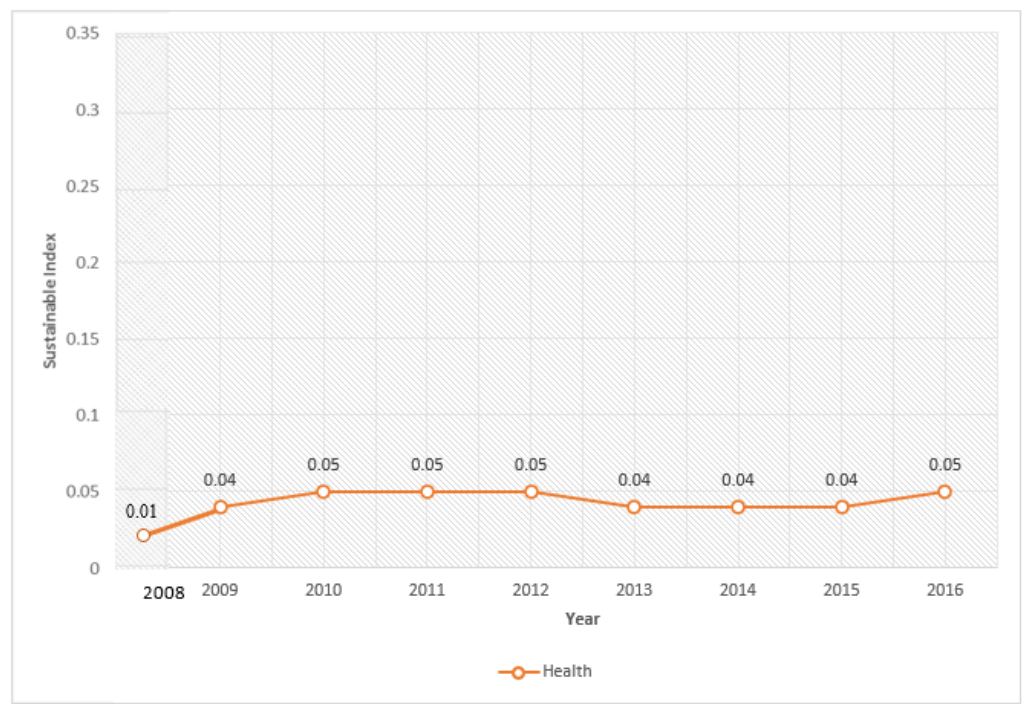

Figure 2: Financial sustainability of sampled public health institutions in the bealth sector.

Source: Authors' Computation (2019)

The figure above represents the summary of financial sustainability of the sampled public health institutions under the health sector. All the positive surplus operating ratios are 
between $1 \%$ and $5 \%$.

Figure 3 is a representation of the budget performance among the MDAs in the health sector. The graph summarizes the ability of the MDAs to manage various types of budgets within the entities. The annual budget manual in health sector is generally made up of recurrent budgets which comprises of personnel cost budget and overhead cost budget and the non-recurrent budget or capital budget prepared by the MDAs within the accounting periods. The ability of the health institution to manage its budget within the allocative resources enhances flawless implementation of the budget. Two ratios are used to assess the budget performance within the sector. The first ratio addresses the ability of the MDAs to meet the revenue budget set in accounting periods in relation to aggregate revenue accruable and collectible from both internal and central authority's sources. The second ratio addresses the ability of the MDAs to minimize cost and achieve the expenditure budget within the accounting period (GFAO,2003, Chaney et al, 2002, Crawford and Associate ,2008). A range of $1 \%$ to $4 \%$ is regarded as a low budget performance while the range of $40 \%-100 \%$ is regarded as a high budget performance. From figure 3, seventeen (17) sampled MDAs under the sector recorded high performance ratios in budget execution which is $68 \%$ of the entire number while eight (8) MDAs recorded low performance in their budget performance which translates to $32 \%$ of the total. The implication is that only (17) seventeen out of the sampled institutions are immune against budget deficits while (7) seven institutions operated under a severe constraints of budget deficits. In addition, these seven (7) MDAs with strict budget constraints might find it difficult to pay the salaries of staff members, settle overhead cost commitments and carry out the needed repairs for the entities. High budget deficits have the capacity to lower the level of infrastructure expenditures and physical capital development. With high budget deficits, the institutions might therefore, be compelled to adopt restrictive financial policy measures by cutting back from capital cost estimates, reducing the size of the payroll or re- postponing public capital spending, recruitment exercise in order to maintain equilibrium (Ndikumana, 2004, Strewn, 2001, Roy, et al., 2006).

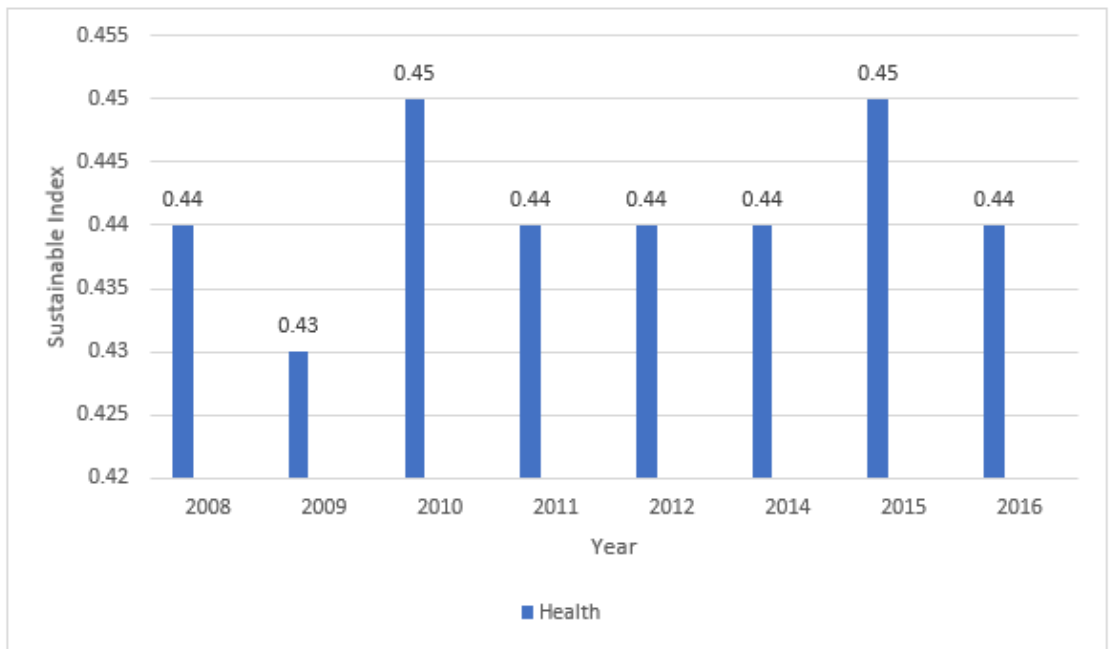

Figure3: Sustainability index of public health institutions on budget performance

Source: Authors' Computation (2019) 
Figure 3 above summarises the sustainability index on operating budget performance of the sampled public health institutions within the health sector.

Figure 4 measures the ability of the MDAs under sector to minimize cost and attain the expenditure budget within the entities. The figure contains ratios used to assess the budget performance of the MDAs in addition to the previous measurements. The cost minimization is a financial strategy aimed at achieving the most cost-effective way of delivering good and services to the required level of quality in an organization. The result of a reduction in cost is higher productivity and better cash inflows. Entity's problem is sometimes behaved in the same direction with firm's problem which maximizes profits by choosing the optimal quantity of inputs to employ and output to produces. The capacity of the entities under the sector appears higher in minimizing costs of inputs. The stark reality is that wastages, redundancies, bureaucracies, perennial losses are the multiple effects in a low- cost minimizing organization.

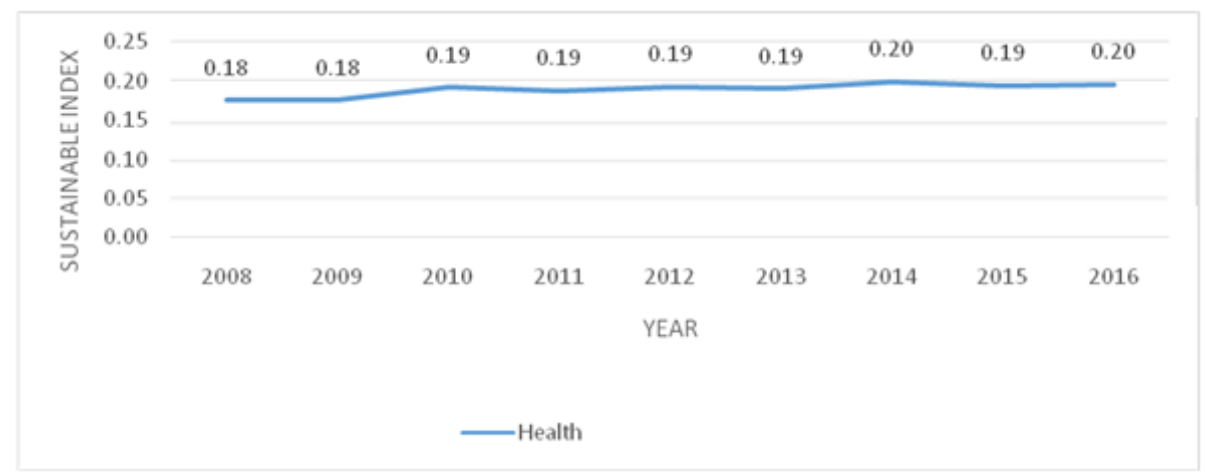

Figure 4: Sustainability Index on Cost minimization and expenditure budget among the MDAs in bealth sector Source: Authors' Computation (2019)

The above figure shows the sustainability index on cost minimization and expenditure budget among the public health institutions within the health sector

Figure 5 represents the fund mobilization performance ratios of the twenty-five sampled MDAs under the health sector. The fund mobilization performance ratio measures the extent to which an entity relies on other external sources for financing. The ratios are measurements of the inability of the health institutions to stand on its own but rather rely on other intergovernmental agencies or central governments or foreign aids for financial resources. A highly fund mobilization performance ratio is suggestive that the health institution is heavily dependent on external resources for survival. It measures the extent of the health institution to absorb shocks in effect of denial from external fund providers or alteration from the streams of funding or allocations and releases to the MDAs. A low fund mobilization performance ratio suggests a mild reliance on the external fund providers for funding in the organization (Nollenberger, 2003, Crawford and Associates, 2008, Cheney et al. 2002, GFOA, 2003). The fund mobilization performance ratios for the sampled MDAs under the sector ranges between 50\% - 67\% implying highly dependence on central authority for funding either for the capital project investment, personnel costs disbursement or overhead cost utilization. The entities suffer in the wake 
of delay or denial in government's releases of personnel cost allocation, capital grants releases and overhead cost finding. The erratic internally generated revenue and the delay in government's releases to the MDAs have been largely responsible for poor investment spending on physical and human capital development in the public health institutions (Mwakalobo, 2009, 2010, 2013 and2015). In the wake of sub-optimal allocation of government resources and declining revenue generation among the MDAs, provision of basic infrastructure that will turn around the lives of teaming poor populace and accentuate their suffering become a mirage. Therefore, it is the less dependence on external funding and financial aids and grants from intergovernmental bodies through aggressive expansion of internally generated revenue base that can balance the trade-off between the delay in external grants and investment spending on physical and human development and also bolster long-term growth and survival of the public health institutions (Clement et al., 2013; Ngomou and Wang, 2015, Palley, 2006). The MDAs under the health sector should therefore stretch themselves a bit to achieve this feat. However, because of the substantial costs expected of capital investments, government under takes a larger proportion of the costs on capital investment to the inclusion of substantial resources on human capital investment within the organization (Mwakalobo, 2015). The major trade- off faced by the public health institution is allocating resources between public investment in both physical and human capital infrastructure and interest payments in the nation accumulated debt. A low level of dependence on the central authority by the MDAs is therefore a panacea for the governments to focus on the multifaceted paradigm.

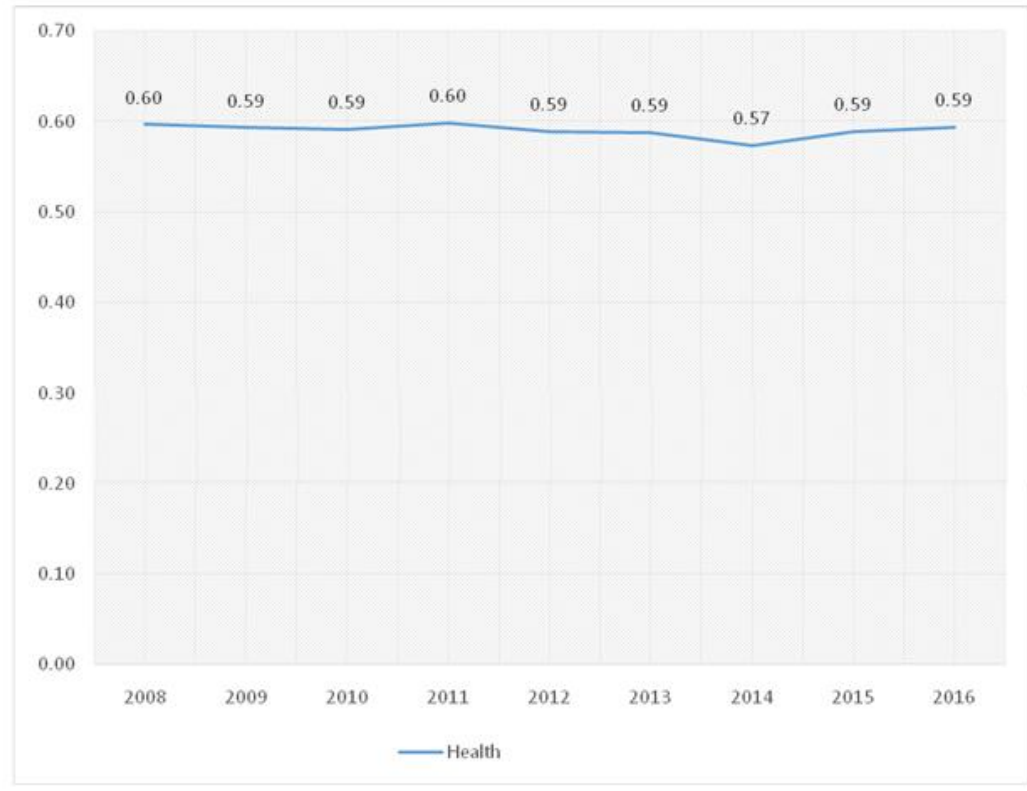

Figure 5: Sustainability Index on budget performance ratios among the public health institutions. Source: Authors' Computation in ini

The figure above shows the sustainability index on fund mobilization capacity among the MDAs in the health sector. 


\section{Conclusion}

The paper investigated the financial sustainability of the public health institutions in Nigeria. The findings revealed that none of the sampled public health institutions could operate at the basic standard level whereby they could generate enough revenue to cover operational expenditures. All the sampled institutions relied heavily on central authority's funding for sustenance. In order to improve the level of sustainability among the public health institutions in Nigeria, the following recommendations are necessary:

The federal government should come up with adequate blueprints for all public health institutions to widen their revenue capacity to generate fund internally. There should be appropriate modalities on how the health institutions can reposition the various revenue units within the organization for sustainable development. The health institution can diversify their revenue bases by engaging on profitable ventures like building of affordable student hostels for the clinical students at competitive commercial rates, operation of bakery services, bookshops, printing press, farm produce, operation of filling stations etc. The current trend in the public health institution funding is the implementation of publicprivate partnership arrangement. This is always the case whereby essential services that cannot be provided only by government's allocations are assisted through the involvement of private individuals who provide needed fund and make the services available as at when due. The health institutions can take advantage of this arrangement.

The cost minimization strategies are potent instruments in stemming the wave of wastages and redundancies in many establishments. As a panacea to the financial crisis that bedevils health institutions, workable strategies to minimize costs and increase revenue should be introduced into the institutions to alleviate the challenges of cash crunch and liquidity problem in the sector. The health institutions should embark on rigorous fund mobilization drives in all areas of operations and activities within the organization. Less reliance should be on the dependence on the inflows from the central authorities.

The public health institutions should stop the lopsidedness in staff appointments to minimize personnel costs wastages. Also, material procurements for all units in the various institutions should follow strict due process so as to prevent double-dealings and enhance transparency in all financial dealings in the MDAs. There should be tight budgetary systems in all the public health institutions that would be strictly based on available revenue generation during the accounting year. Bounded goods should be discouraged in all the institutions as a matter of policy.

The institutions should ensure that confirm that both budgetary provision and fund availability should always precede procurement processes for all items of purchases. The sector should embark on needs assessment strategies in all the institutions to demarcate needs from wants. Each health institution should identify areas of acute shortage for both personnel staff and material needs and institutional focus should be on such critical areas. Efforts should equally be on deck to eliminate all slacks in both personnel cost allocations and overhead costs expenditure.

The central government should create incentives for all the health institutions to expand growth and earning potentials. This will enable financial resources needed to improve health facilities in the sector. The study, therefore, concluded that the federal government should formulate policies that will make the public health institutions widen their internally 
generated revenue capacity and reduce the reliance on central authority funding for improved sustainability.

\section{References}

Akindele, S. T. \& Obiyan, O. R. (2002). Fiscal federalism and Local Government Finance in Nigeria: An examination of revenue, rights and fiscal jurisdiction contemporary issues in public administration. Bolabay publications, $46-64$.

Albertini, E. (2013). Does Environmental Management improve financial performance? A meta-Analytical Review. Journal of organizational Environment, 26(1), 431 -457.

Ali, A; Haiham, N. \& Nilesh, K. (2018). The impact of sustainability practices on corporate financial performance: Literature Trends and Future Research Potential. Journal of Sustainability, 10(3), 1 25 .

Askin, J. (2004). Performance Management and Organizational Intelligence: Adopting the balanced scorecard in Larik Municipality. International Public Management Journal, 7(3), 415 - 438.

Bassey, U. (2015). Falling oil prices: State Consider Slashing Political Office Holder Pay. Premiums Times, 25 $-26$

Chaney, B. A., Mead, D. M. \& Schormann, K. R. (2002). The new government financial reporting model. Journal of Government financial management. Spring 2002. Pp. 27 - 31

Clement, B. Bhattacharya, R., \& Nguyen, T. Q. (2013). External debt public investment and growth in lowincome countries. IMF working paper 03/249, Washington, DC., IMF.

Crawford and Associates, P. C. (2008). The Performance Oklahoma City at www.crawfordpass.com

De Souza Cunha, F. A. F., Samanez, C. P. (2013). Performance Analysis of Sustainability Investments in the Brazillian Stock Market: A study about the corporate Sustainability Index. Journal of Business Ethics, 117(2),19- 36.

Douglas, A. (2010). Stimulating internally generated revenue in Bayelsa States. International Journal of Management Research, 2(5), $76-88$.

Ekpo, A. \& Ndebbio, J. (1998). Local Government Fiscal Operations in Nigeria, AERC Research Paper No. 73. African Economic Research Consortium, Nairobi, Kenya.

European Journal of Business and Management, 70, 184 - 193

Goldratt, E. M. (1998). What is this thing called the theory of constraints? North River Kaplain, R. S. \& Norton, D. P. (1992). The balanced Scorecard - measures and drive performance, Harvard Business Review, Jan - Feb, PP.71 -79

Government Finance Officers' Association (2003). Recommended Practice. The Use of trend data cited comparative data for financial analysis available at www.gfo.org

Hahn, T. \& Figge, F. (2011). Beyond the Bounded Instrumentality in current sustainability Research: Toward an inclusive Notion of Profitability. Journal of Business Ethics, 104 (2), 325 - 245.

Ibeogu, A. \& Ulo, F. (2015). Internally generated revenue in the local government system and sustainable community development in Nigeria: A study of Abakaliki Local Government Area, Ebonyi State. International Journal of Research in Business management, 3(11), 111 - 120.

Kaplan, R. S. \& Norton, D. P. (1992). The Balanced Scorecard measures that Drive Performance. Harvard Business Review, Jan. - Feb., 71 - 79

Kloof, I. \& Martin, J. (2000). Strategic Performance Management: A Balanced Approach to Performance Management Issues in Local Government: Management Accounting Research, 2(1), 231 - 251

Management Advisory Board (1997) Beyond being country. Effective financial Management in the APS 1998 and beyond.

Moldavska, A. (2017). Defining Organizational content for corporate Sustainability Assessment: Cross Disciplinary Approach Sustainability, 9(1), 2365 -2378.

Mwakalobo, A. B. S. (2010). The dynamics of Tax Performance in Tanzania: An empirical investigation of short-and-Long-run relationship. Eastern and Southern African Journal of Agricultural economics and Development, 3(2), $201-225$

Mwakalobo, A. B. S. (2009). Economic reforms in East African Countries: The impacts on government revenue and public investment. A Ph.D thesis, University of Massachusetts - Amherst, USA. 
Mwakalobo, AB.S. (2013). Dynamics of revenue generation in Tanzania, Kenya and Uganda: A co-integration and error-correction modelling approach. A paper submitted for publication in the development, Southern Africa

Mwakalobo, A.B.S. (2015). Dynamics of revenue generation capacity in developing countries: Implementation for physical and human capital development in Tanzania, Kenya and Uganda. African Journal of economic review, 3(1), $21-38$.

Ndikumana, L. (2004). Fiscal Policy, Conflict and reconstruction in Burundi and Rwanda. In Addition, T \& A Roe (eds), Fiscal Policy for development, Poverty, reconstruction and Growth, Palgrave, Macmillan, pp. $274-302$

Ngomou, S. I. \& Man Wang (2015). Measuring performance in public sector organizations: evidence from local government authorities in Tanzania.

Nnanseh, M. \& Akpan, S. S. (2013) Internally Generated Revenue (IGR) and Infrastructural Development in Akwa Ibom State. European Journal of Business and Management, 5(31), 164 - 172

Nollenberger, K. (2003). Evaluating financial condition. A handbook for Local Government, fourth ed. Washington DC. International City/Country management Association: A revision of the original 1980. Text by Sanford M. Groves and Maureen G. Valente.

Oladejo, M. O. \& Alade, B. J. (2017). Internally Generated Revenue and the Revenue Profile of selected South Western State Governments in Nigeria. International Journal of Research in Business Management, 5 (12), $13-28$.

Omotosho, F. (2009). Administrative Problems of State Creation in Ekiti State, Nigeria.

Olusola, O. (2011). Boosting internally generated revenue of local governments in Ogun State, Nigeria. European Journal of Humanities and Social Sciences, 8(1), $336-348$.

Robinson, M., Kleffner, A., Bertels, S. (2011). Signalling sustainability Leadership: Empirical evidence of the value of DJSI membership. Journal of Business Ethics, 101(2), 493 - 505.

Roy, R. Heaty, A. \& Letouze, E. (2006). Fiscal space for public investment: Towards a Human Development Approach. Paper Prepared for the G-24. Technical meeting - Singapore, September 13 - 14

Salawu, R. O., \& Odewole, P. O. (2020). Efficiency of Personnel Costs Utilization among MDAs in Nigeria: The Data Envelopment Analysis Approach. International Journal on Governmental Financial Management 20(1), 65 - 82

Sheh, N. (2014). Developing Financial Distress Prediction Modes using Edge Receiver Partitioning Techniques. A study of Australian Mining Performance. Review of integrative Business and Economic Research, 3(2), 103 -143

Strecon, J. (2001). Determinants of Public Capital Spending in less developed countries. University by Groningen and Cesifo Munich.

Striteska, M. (2010). Role Nefinancnizh Meritek Ve Strategic Kem Rizeni. In Manazerska Etika, Di/8, Inspirace Pro 21, Steleti: Univerzita Tomak Bati Vezline, 978 - 80 - 7318 - 941-9

Xiao, Y; Faff, R., Gharghori, P. \& Lee, D. (2013). An empirical study of the World Price Sustainability. Journal of Business Ethics, 114(2), 297310.

$\mathrm{Yu}, \mathrm{M}$; Zhao, R. (2015). Sustainability and firm valuation: An international investigation. International Journal of Accounting and information Management, 23(2), 289 - 307 